\title{
PRODUKSI DAN LAJU DEKOMPOSISI SERASAH MANGROVE (Sonneratia sp) DI KAWASAN HUTAN MANGROVE BAHOWO, KELURAHAN TONGKAINA KECAMATAN BUNAKEN SULAWESI UTARA
}

\author{
(Production and Decomposition Rate of Mangrove (Sonneratia sp.) Litter in Bawoho \\ Mangrove Forest, Tongkaina Village, Bunaken District, North Sulawesi)
}

\author{
Yunus Watumlawar ${ }^{\star}$, Calvyn F.A. Sondak ${ }^{1}$, Joshian N.W. Schaduw ${ }^{1}$, \\ Jane M. Mamuaja ${ }^{1}$, Suria Darwisito' ${ }^{1}$, Jardie Andaki ${ }^{2}$
}

1. Program Studi IImu Kelautan Fakultas Perikanan dan IImu Kelautan, Universitas Sam Ratulangi, Manado.

2. Program Studi Agrobisnis Perikanan Fakultas Perikanan dan IImu Kelautan, Universitas Sam Ratulangi, Manado.

*e-mail : yunuswatumlawar@yahoo.com

Mangrove litter has a very important function for the mangrove ecosystem and surrounding area, include to keeping mangrove forest soil fertility. Soil and plant fertility depends on litter productivity and decomposition rate. The litter will be decomposed as organic matter such donor to the mangrove soil, and evenwally become a food source for infauna. This study goals was to find out (Sonneratia sp.) litter production and decomposition rate. The results of the study showed that the highest production of (Sonneratia sp.) litter was found in plot 1 (83.55 $\mathrm{g} / \mathrm{m}^{2} /$ day), follow by plots $3\left(55.30 \mathrm{~g} / \mathrm{m}^{2} /\right.$ day $)$, plots $2\left(45.87 \mathrm{~g} / \mathrm{m}^{2} /\right.$ day $)$ and plot $4\left(39.30 \mathrm{gr} / \mathrm{m}^{2} /\right.$ day $)$ respectively. The highest decomposition percentage and decomposition rate per day was found in plot 4 , which decomposed on day $30^{\text {th }}$, followed by plot $315.70 \%$ with decomposition rate $1,57 \%$ per day, plot 1 with the remaining final weight of $16.32 \%$ with a decomposition rate per day of $1.09 \%$. The lowest was in plot 2 about $17.16 \%$ with a decomposition rate per day $1.14 \%$.

Keywords : Litter, Production, Decomposition, Mangrove, Sonneratia sp.

Serasah hutan mangrove memiliki fungsi yang amat penting bagi ekosistem mangrove, diantaranya untuk mempertahankan kesuburan tanah hutan yang bersangkutan. Kesuburan tanah dan tanaman bergantung pada produktivitas dan laju dekomposisi serasah. Serasah akan mengalami dekomposisi, memberikan sumbangan bahan organik bagi tanah hutan, serta menjadi sumber makanan bagi kehidupan fauna tanah. Penelitian ini dilakukan dengan tujuan untuk memberikan informasi mengenai produktvitas serasah mangrove (Sonneratia sp.) dan laju dekomposisi. Hasil penelitian menunjukkan bahwa total produksi serasah mangrove (Sonneratia sp.) yang terbesar ditemukan pada plot (1) yaitu $\left(83,55 \mathrm{gr} / \mathrm{m}^{2} /\right.$ hari), kemudian plot 3 $\left(55,30 \mathrm{gr} / \mathrm{m}^{2} /\right.$ hari), selanjutnya plot $2\left(45,87 \mathrm{gr} / \mathrm{m}^{2} /\right.$ hari $)$, dan plot 4 menghasilkan produksi serasah sebesar $(39,30 \mathrm{gr} / \mathrm{m} 2 / \mathrm{hari})$. Total rata-rata persentase dekomposisi dan laju dekomposisi per hari yang terbesar/tercepat terdapat pada plot 4 yaitu terurai semua pada hari ke-30, kemudian diikuti oleh plot 3 dengan sisa bobot akhir yaitu sebesar 15,70 \% dengan laju dekomposisi per hari 1,57 \%, kemudian plot 1 dengan sisa bobot akhir yaitu sebesar 16,32 \% dengan laju dekomposisi per hari 1,09\%, dan yang terendah terdapat pada plot 2 sebesar $17,16 \%$ dengan laju dekomposisi per hari 1,14\%.

Kata kunci : Produksi serasah, Dekomposisi serasah mangrove Sonneratia sp.

\section{PENDAHULUAN}

Mangrove merupakan ekosistem yang berada pada wilayah intertidal, dimana pada wilayah tersebut terjadi interaksi yang kuat antara perairan laut, payau, sungai dan terestrial. Interaksi ini menjadikan ekosistem mangrove mempunyai keanekaragam yang tinggi baik berupa flora maupun fauna.

Tumbuhan

mangrove merupakan sumber makanan potensial, 
dalam berbagai bentuk bagi semua biota yang hidup di ekosistem mangrove. Berbeda dengan ekosistem pesisir lainnya, komponen dasar dari rantai makanan di ekosistem hutan mangrove bukanlah tumbuhan mangrove itu sendiri, tapi serasah yang berasal dari tumbuhan mangrove seperti (daun, ranting, buah, batang) (Bengen, 2004).

Serasah hutan mangrove memiliki fungsi yang amat penting bagi ekosistem mangrove, diantaranya untuk mempertahankan kesuburan tanah hutan yang bersangkutan. Kesuburan tanah dan tanaman bergantung pada produktivitas dan laju dekomposisi serasah (Aprianis, 2011). Serasah akan mengalami dekomposisi, memberikan sumbangan bahan organik bagi tanah hutan, serta menjadi sumber makanan bagi kehidupan fauna tanah. Akumulasi bahan organik hasil dekomposisi serasah hutan mangrove bermanfaat memperkaya hara pada ekosistem mangrove sebagai daerah asuhan dan pembesaran (nursery ground), daerah pemijahan (spawning ground), dan perlindungan bagi aneka biota perairan (Wibisana, 2004).

Dekomposisi serasah merupakan proses perubahan bahan organik yang berasal dari hewan atau tumbuhan, baik secara fisik maupun kimia menjadi senyawa anorganik (mineral) sederhana oleh mikroorganisme tanah. Kecepatan proses dekomposisi tergantung pada kondisi lingkungan, jenis tanaman, komposisi bahan kimia tanaman dan umur tegakan. Manfaat yang dapat dihasilkan berupa nutrisi untuk pertumbuhan tanaman secara normal (Dita, 2007).

Menurut Kuriandewa (2003) serasah yang jatuh ke lantai hutan tidak langsung mengalami pelapukan oleh mikroorganisme, tetapi memerlukan bantuan makrobentos. Makrobentos berperan sebagai dekomposer awal yang bekerja dengan cara mencacah daun menjadi bagian-bagian kecil yang kemudian dilanjutkan oleh organisme kecil, yakni mikroorganisme (bakteri dan fungi) yang menguraikan bahan organik menjadi protein dan karbohidrat.

Penelitian ini dilakukan dengan tujuan untuk memberikan informasi mengenai: produktvitas serasah mangrove (Sonneratia sp.) dan laju dekomposisi serasah mangrove di kawasan hutan mangrove Bahowo, Kelurahan Tongkaina, Kecamatan Bunaken, Sulawesi Utara

\section{METODE PENELITIAN}

\section{Waktu dan Tempat Penelitian}

Berdasarkan tujuan yang ditetapkan, maka kegiatan penelitian ini difokuskan bagaimana mengetahui serta menganalisis produksi dan laju dekomposisi serasah mangrove yang berada di kawasan hutan mangrove Bahowo, Kecamatan Bunaken, Sulawesi Utara. dengan bantuan peralatan dan bahan, serta prosedur kerja yang dipaparkan berturut-turut dibawa ini.

Penelitian mengenai produksi dan laju dekomposisi serasah mangrove Sonneratia sp. dilakukan pada bulan Juni - July 2018 di hutan mangrove Bahowo, Kelurahan Tongkaina, Kecamatan Bunaken, Sulawesi Utara (1034'57.22" 1034'58" LU dan 124049'19,30" $124^{\circ} 49^{\prime} 18^{\prime \prime}$ BT

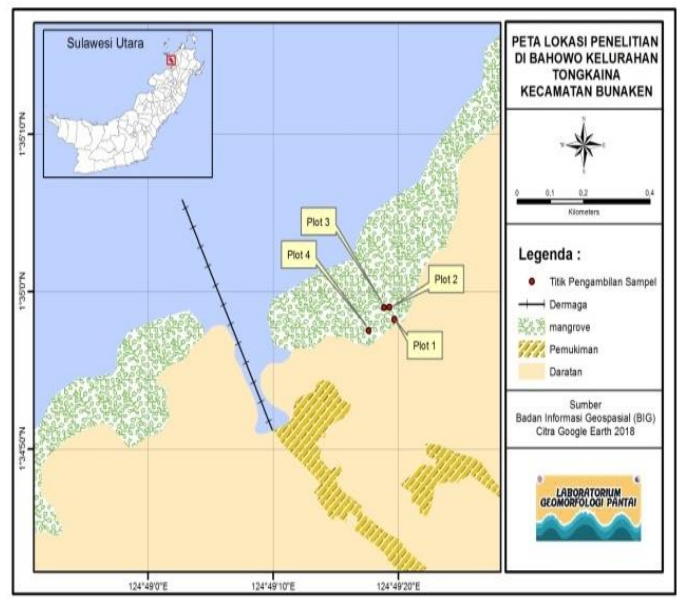

Gambar 1. Peta Lokasi Penelitian 


\section{Metode Kerja}

Pengambilan data tegakan mangrove dilakukan dalam 4 plot berukuran $10 \times 10 \mathrm{~m}^{2}$, dengan jarak antar plot sejauh $10 \mathrm{~m}$.

Jaring penampung ukuran $1 \times 1$ meter diletakan di bawah konopi mangrove. Pengambilan samp dilakukan setiap 10 hari selama 50 hari. Sampel serasah kemudian ditimbang berat basah. Selanjutnya sampel di keringkan di dalam oven selama 24 jam pada suhu $80^{\circ} \mathrm{C}$.

Serasah mangrove, yang telah keringkan pada suhu $80^{\circ} \mathrm{C}$ selama 24 jam dan di timbang (ketelitian 0,01gram), diambil sebanyak 10 gram kemudian di masukkan ke kantong serasah dan di ikat pada akar pohon mangrove. Sampel di ambil setiap 10 hari selama 50 hari. Bersihkan dari lumpur, dan dikeringkan pada temperatur suhu $80^{\circ} \mathrm{C}$ selama 24 jam kemudian di timbang untuk mendapatkan berat akhir.

\section{Analisis Data}

\section{Pengukuran Serasah}

Produktifitas

Analisis produksi serasah dilakukan menggunakan persamaan Hamidy, dkk. (2002).

Rumus : Berat kering $=\mathrm{Gbk} / \mathrm{m}^{2} /$ hari Ket : gbk = gram berat kering $\mathrm{m}^{2} /$ hari $=$ meter kuadran per hari

\section{Pengukuran Laju Dekomposisi Serasah}

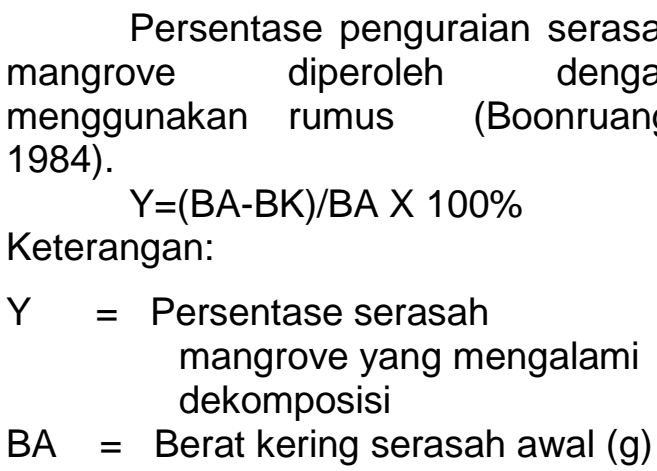

$\mathrm{BK}=$ Berat kering serasah setelah waktu pengamatan ke-t (g)

Untuk mendapatkan nilai persentase kecepatan dekomposisi serasah per hari:

$$
\begin{aligned}
& X=Y / D \\
& \mathrm{X}=\text { Persentase kecepatan } \\
& \text { dekomposisi serasah per hari } \\
& \mathrm{Y}=\text { Persentase serasah } \\
& \text { mangrove yang mengalami } \\
& \text { dekomposisi } \\
& \mathrm{D}=\text { Lama pengamatan (hari). }
\end{aligned}
$$

\section{HASIL DAN PEMBAHASAN}

\section{Produktivitas Serasah Mangrove}

Total produksi serasah yang tertinggi terdapat pada plot 1 yaitu $83,55 \mathrm{gr} / \mathrm{m}^{2} /$ hari kemudian dikuti oleh plot 3 yang menghasilkan produksi serasah sebesar $55,30 \mathrm{gr} / \mathrm{m}^{2} /$ hari, selanjutnya plot 2 menghasilkan produksi serasah sebesar 45,87 $\mathrm{gr} / \mathrm{m}^{2} /$ hari dan plot 4 menghasilkan produksi serasah sebesar 39,30 $\mathrm{gr} / \mathrm{m}^{2} /$ hari. Hasil ini lebih tinggi dari (Tidore.,et al. 2018) yang mendapatkan produksi serasah $\mathrm{gbk} / \mathrm{m}^{2} / 28 \mathrm{hr}, \quad 1,83$ $\mathrm{gbk} / \mathrm{m}^{2} /$ hari di Desa Lansa Kecamatan Wori Kabupaten Minahasa Utara.

$$
\text { Kerapatan }
$$

mangrove mempengaruhi produksi serasah mangrove dimana semakin tinggi kerapatan pohon semakin tinggi

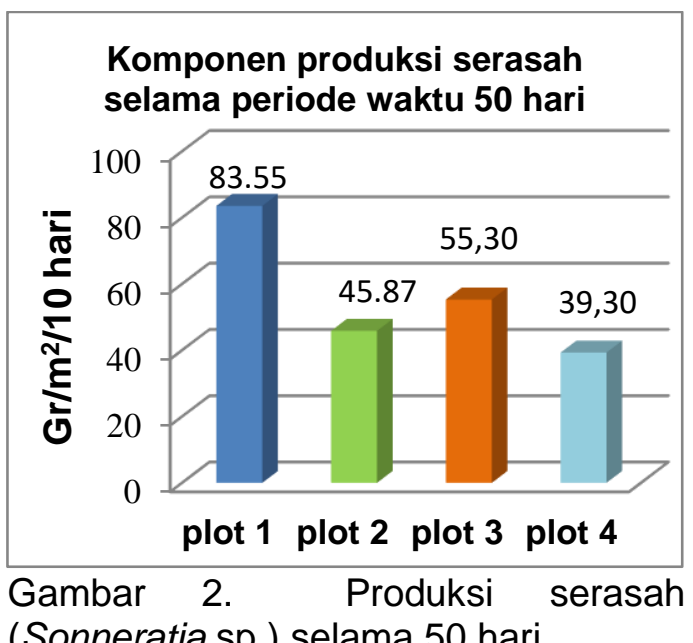

(Sonneratia sp.) selama 50 hari. 
produksi serasah (Soedarti, 2011). Faktor cuaca seperti hujan mempengaruhi tingkat produktivitas serasah hutan mangrove. Produksi serasah akan tinggi disaat musim hujan dibandingkan pada musim panas, hal ini disebabkan karena rendahnya masa jenis daun yang membuat daun mudah jatuh (Soedarti, 2011). Selain itu faktor lain yang juga mempengaruhi produksi serasah adalah faktor musim dan kecepatan angin (Widhitama et al, 2016). Komponen dari hasil total produktivitas serasah yang di ambil pada satu jenis mangrove dapat di lihat pada gambar berikut ini.

\section{Laju Dekomposisi Serasah Mangrove}

Hasil penelitian memperlihatkan adanya perubahan berat kering akhir dan laju dekomposisi serasah mangrove Sonneratia sp yang bervariasi. Rata-rata sisa bobot kering akhir tertinggi terdapat di plot 4 yaitu sebesar 35,27\% dengan laju dekomposisi per hari 3,53\%, kemudian dikuti plot 2 dengan sisa bobot akhir yaitu sebesar 17,16\% dengan laju dekomposisi per hari $1,14 \%$, plot 1 dengan sisa bobot akhit yaitu sebesar $16,32 \%$ dengan laju dekomposisi per hari $1,09 \%$ dan plot 3 dengan sisa bobot terendah yaitu $15,70 \%$ dan laju dekomposisi per hari $1,57 \%$

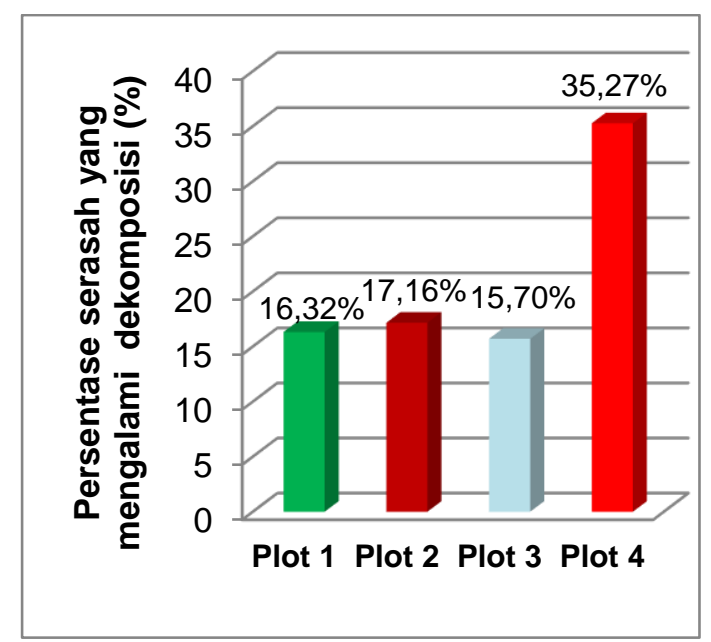

Gambar 3. Persentase sisa bobot akhir serasah mangrove (Sonneratia sp.) selama 50 hari.

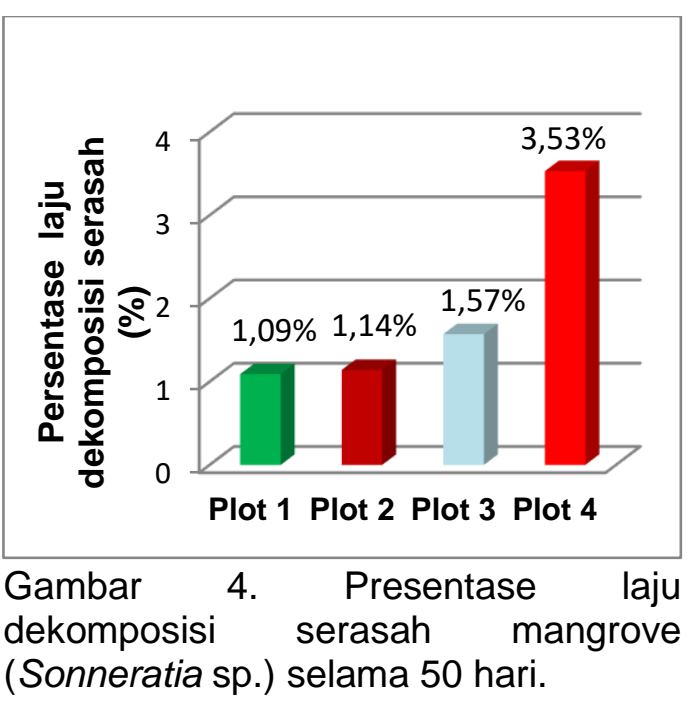

Penelitian ini menemukan bahwa nilai bobot kering akhir dan laju dekomposisi terendah terdapat pada plot 4 , yang artinya plot 4 mengalami laju dekomposisi paling cepat dibandingkan dengan plot 1, 2 dan 3 .

Dengan adanya hal tersebut dapat dijelaskan bahwa penurunan bobot serta laju dekomposisi serasah meningkat dengan adanya interaksi antara substrat, biota dan lingkungan. Dekomposisi serasah berhubungan erat dengan faktor lingkungan dan kualitas serasah. Kualitas serasah menunjukan bagaimana fungsi serasah menguntungkan terhadap komunitas mikroorganisme sebagai sumber energi dan nutrisi (Murphy. et.al.,1998 dalam Sari et al. ( 2014).

Komposisi unsur karbon (C), nitrogen $(\mathrm{N})$ dan fosfor $(\mathrm{P})$ dalam daun mangrove juga mempengaruhi proses dekomposisi serasah. Serasah dengan kandungan $\mathrm{N}$ yang tinggi lebih cepat terdekomposisi karena lebih mudah dicerna (Choong et al, 1992). Rasio dari C:N juga berkontribusi dalam proses dekomposisi dimana rasio C:N yang rendah bisa mempercepat proses dekomposisi (Bosire et al. 2005). Durasi dari perendaman pasang surut juga mempengaruhi tingkatan dekomposisi serasah mangrove untuk hancur (Mfilinge et al. 2002; Bosire et al., 2005). 


\section{Makrozoobenthos}

Makrozoobentos yang ditemukan di dalam plot yaitu Chicoreus capucinus, Metaplax sp., Episesarma sp., Thalassina anomala Nerita undata, Uca sp. dan Glycera sp.

Secara ekologis makrozoobentos memiliki peranan yang besar dalam kaitannya dengan rantai makanan komponen biotik dikawasan hutan mangrove serta berperan dalam proses dekomposisi serasah. Informasi ini didukung sesuai literatur dari (Riski et al. 2016). Peranan pada masingmasing spesies dapat dijelaskan bahwa sebagai dekomposer awal, crustacea dan gastropoda bekerja mencacahcacah serasah menjadi bagian-bagian kecil kemudian akan dilanjutkan oleh polychaeta dan mikroorganisme lainnya (Arief. 2003).

\section{KESIMPULAN}

Berdasarkan tujuan dari penelitian yang dilakukan di kawasan hutan mangrove Bahowo, Kecamatan Bunaken, Sulawesi Utara. Hasil dari produksi dan laju dekomposisi serasah mangrove (Sonneratia sp.) dapat disimpulkan bahwa:

1. Total produksi serasah mangrove (Sonneratia sp.) yang terbesar adalah terdapat pada :

- $\quad$ Plot 1 Yaitu $83,55 \mathrm{gr} / \mathrm{m}^{2} / \mathrm{hari}$

- $\quad$ Plot 2 Yaitu $45,87 \mathrm{gr} / \mathrm{m}^{2} /$ hari

- Plot 3 Yaitu 55,30 gr/m²/hari

- Plot 4 Yaitu 39,30 gr/m²/hari

2. Total rata-rata persentase dekomposisi dan laju dekomposisi per hari selama waktu penelitian (50 hari).

- $\quad$ Plot 1 Yaitu 16,32\% dengan laju dekomposisi per hari 1,09\%

- $\quad$ Plot 2 Yaitu 17,16\% dengan laju dekomposisi per hari 1,14\%

- $\quad$ Plot 3 Yaitu 15,70\% dengan laju dekomposisi per hari 1,57\%

- $\quad$ Plot 4 Yaitu 35,27\% dengan laju dekomposisi per hari 3,53\% (hari ke 20).

\section{DAFTAR PUSTAKA}

Arief, A. 2003. Hutan Mangrove Fungsi dan Manfaat. Kanisius. Yogyakarta.

Aprianis, Y. 2011. Produksi dan Laju Dekomposisi Serasah Acacia crassicarpa A. Cunn. Di PT. Arara Abadi. Balai Penelitian Hutan Penghasil Serat. 4 (1) hal 41-47.

Boonruang, P. 1984. The rate of degradation of mangrove leaves, Peninsula of Thailand. In: Soepadmo, E., Rao, A.N., Macintosh, D.J. (Eds). Proceedings of The Asian Symposium on Mangrove Environment Research and Management. University of Malaya and UNESCO. Kuala Lumpur. 200-208 pp.

Bengen DG. 2004. Sinopsis Ekosistem dan Sumberdaya Alam Pesisir dan Laut serta Prinsip Pengelolaannya. Pusat Kajian Sumberdaya Pesisir dan LautanInstitut Pertanian Bogor.

Bosire, J.O., Guebas, F.D., Kairo J.G., Kazungu, J., Dehairs, F., Koedam, N. 2005. Litter degradation and $\mathrm{CN}$ dynamicsin reforested mangrove plantations at Gazi Bay Kenya. Biological Conservation, 126:287-295.

Choong, V.C., Sesakumar, A., Leh, M.U.C., Cruz, R.D. 1992. The fish and prawn communities of a Malaysian coastal mangrove system, with comparisons to adjacent mud flats and inshore waters. Estuarine, Coastal and Shelf Science 31:703-722.

Dita, I.F, 2007. Pendugaan Laju Dekomposisi Serasah Daun Shorea balangeran (Korth.)Burck dan Hopea bancana (Boerl.) Van 
Slooten Di Hutan Penelitian Dramaga, Bogor, Jawa Barat. Fakutas Kehutanan, Institud Pertanian Bogor. p 32.

Hamidy, R., Sastrodiharjo, S., Ardianto, Taufiturrahman. 2002. Struktur Komunitas dan Produksi Serasah Mangrove di Dumai, Riau, Biologi 2 (13):755-768.

Kuriandewa, T.E. 2003. Produksi Serasah Hutan Mangrove di Kawasan Suaka Margasatwa Sembilang, Provinsi Sumatera Selatan. Pesisir dan Pantai Indonesia. Pusat Penelitian Oseanografi LIPI, Jakarta.

Mfilinge, P.L., Meziane, T., Bachok, Z., Tsuchiya, M. 2005. Litter dynamics and particulate organic matter outwelling from a subtropical mangrove in Okinawa Island, South Japan. Estuarine, Coastal and Shelf Science, 63:301-313.

Murphy, K.L., Jeffrey,M.K., Klopatek, C.C. 1998. The Effects of Litter Quality and Climate on Decomposition Along an Elevantional Gradient. Arizona State University,USA.

Riski, E,D., Yunasfi Y., Wahyuningsih H. 2016. Laju Dekomposisi Serasah Daun Rhizhopora Apiculata Pada Berbagai Tingkat Salinitas Di Kampung Nypa Desa Sei Nagalawan Kecamatan Perbaungan. Peronema Forestry Science Journal, 5 (3), 175-187.

Soedarti, T., Widyalekson, T., Sopana, A.G. 2012. Produktifitas Serasah Mangrove Dikawasan Wonorejo Pantai Timur Surabaya. Jurnal Fakultas Sains dan Teknologi, Universitas Airlangga, Surabaya.

Sari, N., Adriman., Nur El Fajri. 2014. The Production and Decomposition Rate of Mangrove
Litter in The Sungai Alam Village, Bengkalis Sub-district, Bengkalis Regency, Riau Province. Jurnal Online Mahasiswa. FPIK Universitas Riau. hal 1-7.

Tidore, F., Rumengan, A., Sondak, C.F.A, Mangindaan, R.E.P, Runtuwene, H.C.C, Pratasik, S.B. 2018. Estimasi Kandungan Karbon (C) Pada Serasah Daun Mangrove Di Desa Lansa,Kecamatan Wori, Kabupaten Minahasa Utara. Jurnal Pesisir dan Laut Tropis, 2 (1):55-56.

Wibisana, T.B. 2004. Produksi dan Laju Dekomposisi Serasah Mangrove di Wilayah Pesisir Kabupaten Berau, Propinsi Kalimantan Timur. IImu Kelautan. Fakultas Perikanan dan IImu Kelautan. Institud Pertanian Bogor.

Widhitama, S. Purnomo, P.Y. Suryanto, A. 2016. Produksi dan laju dekomposisi serasah mangrove berdasarkan tingkat kerapatannya di Delta Sungai Wulan, Demak, Jawa Timur. Diponegoro. Journal of Maquares, 5(4):311-319. 